\title{
Development of Extension Service Utilisation Index
}

\author{
B. Neethi* and A. Sailaja \\ Department of agricultural extension, college of agriculture, Acharya N.G Ranga Agriculture \\ University, Rajendranagar, Hyderabad, India \\ *Corresponding author
}

\begin{abstract}
A B S T R A C T
\end{abstract}
Ex- post facto research design was followed for carrying out the study in the State of Andhra Pradesh. Sample comprise of 120 farmers randomly from four randomly selected mandals of Mahabunagar district which was a purposive selection. Two parameters namely extent of utilisation and extent of adoption were considered for the construction of utilisation index. To study the relevance of different aspects of each of DAATTC services

\section{Keywords}

Development, Extension service, Utilisation index

Article Info

Accepted:

20 April 2018

Available Online:

10 May 2018 judges were contacted. The aspects under each of the services whose values were more than one were finally selected. To measure the adoption, recommended practices in cotton crop were selected to prepare the schedule in consultation with scientists of DAATTC, teaching staff of college of agriculture, Rajendranagar and officials of state department of agriculture and other staff. The respondents were asked to respond to each sun item of adoption of these practices with respect to their extent of adoption of respondents. Majority of respondents had medium utilisation of services of DAATTC. As there was less utilisation of services through assessment and refinement of technologies and services through information centre and supply of information material, the scientists need to assess and refine the technologies immediately and give feed back to farmers, so that the farmers get satisfied. To develop the information centre and supply the information material, sufficient budget has to sanction so that technologies get widely publicized these will ultimately result in effective service utilisation. Finally, it can be concluded that the utilisation of DAATTC services helps the farmers in increasing the level of knowledge, skill and adoption of technology.

\section{Introduction}

Extension is a series of embedded communicative intervention that is meant to develop or induce innovations which help to resolve problematic situations. Agriculture is the most well integrated sector of the economy throughout the world and agricultural extension is the nucleus of the agriculture cell. The development of agriculture is mostly dependent on the effectiveness of agricultural extension - its services, methodologies and processes. Extension network is effective there reason proper agricultural technology will not reach to its users for its efficient adoption.

Extension as an essential pillar for research and development however, unfortunately, a somewhat unhealthy perception of extension prevails in many countries, caused by a weak 
extension lobby, faulty initial organizational set-up, an inherent lack of trust in extension by most of the research organizations and traditionally poor career development conditions in profession of extension.

Agricultural research agendas remain largely academic unless extension workers provide input in terms of the identified and as - yet unsolved field problems of the farmers. Research focusses on the technical aspects for generating useful technologies, while extension focuses on the acceptance, utilisation and finally adoption of technologies by users.

This study which first of its kind made an attempt to study the utilization of services delivery of DAATTC by farmers of different socio-economic status. This study also enables to formulate a strategy in effective delivery of services to enable effective utilization by farmers, thus it serves as ready-reckoner in ANGRAU planners to put forth the strategy into implementation and thus the farming community.

\section{Materials and Methods}

\section{Utilisation of DAATTC services}

It is operationalised as extent of utilisation of services and adoption of a technology by selected farmers.

For this, a set of aspects was framed to elicit utilisation of DAATTC services and were prepared in consultation with the expert scientists and extensionists.

Construction of the index: Two parameters namely extent of utilisation and extent of adoption were considered for the construction of utilisation index. To study the relevance of different aspects of each of DAATTC services judges were contacted.
Extent of utilisation: The following procedure was followed towards extent of utilisation of services. The services selected for the study was those provided by DAATTC were listed different aspects under each of the services were formulated. This was given to those working in various extension units a comprising of twenty judges. They were requested to rate each aspect on a three point continuum according to their relevance ranging from 'highly relevant' (3), 'relevant' (2) and 'not relevant' (1) with the respective scores accorded. Frequency of respondents against each aspect were multiplied with respective scores, the total scores for each aspect were worked out and the medium value of each aspect was arrived at by dividing total score with number of respondents. The medium value for each aspect was rounded off to the nearest integer. These values have been taken as weights for different aspects. Those aspects whose medium values were finally one and less than one were deleted. The aspects under each of the services whose values were more than one were finally selected and enclosed in Table 1.

Those aspects under each of the services included various items like information coverage, timeliness, suitability, accessibility and perception towards past performance. The respondents were asked to initial respond to each of these aspects with relevant scores of two or one accorded. Then they were asked to state their extent of utilisation on a three point continuum namely highly utilised (3), partially utilised (2), less utilised (1) with respective scores accorded. Full utilisation is operationalised as the utilisation of services regularly in each season in every year by the respondents to make improvement in one or all behavioral components namely knowledge, attitude and skill. Partial utilisation is operationalised as the utilisation of services at least once in a year continuously for three years by the respondents to make 
improvement in one or all behavioral components. Less utilisation is operationalised as the utilisation of services once in three years by the respondents to make improvement in one or all behavioral components. The final score of a respondent against each aspect was obtained by adding these two score i.e., regarding each item of aspect and extent of utilisation against each of these aspects.

The maximum score was 198 and minimum score obtained was 120 . The total score of respondents was arrived by multiplying the frequency of responses of each aspect of service with corresponding final score. The mean score of each aspect of service was arrived from dividing total score with number of respondents and aspects were ranked based on mean scores.

\section{Categorization}

The respondents were grouped into following three categories i.e. low, medium and high utilisation of DAATTC services based on inclusive class interval technique.

\section{Extent of adoption}

Adoption is the acceptance and practical application of a particular recommended practice. To measure the adoption, recommended practices in cotton crop were selected to prepare the schedule in consultation with Scientists of DAATTC, teaching staff of College of Agriculture, Rajendranagar and officials of State department of agriculture and other staff. The respondents were asked to respond to each sun item of adoption of these practices with respect to their extent of adoption on a five point continuum namely 'full adoption' (5), 'partial adoption' (4), 'less adoption' (3), 'symbolic adoption' (2), 'non adoption' (1) with respective weightages accorded. Full adoption is operationalised as the adoption of stated practice completely and regularly in each season of a year continuously for three year period. Partial adoption is operationalised as the adoption of only a part or whole of recommended practice once in year continuously for three year period. Less adoption was operationalised as the adoption of only a part of recommended practice once in a three years period. Symbolic adoption was operationalised as the practices over which he has taken mental decision but not taken up physical action over them. Non adoption was operationalised as that recommended practices were not all adopted by the farmer.

The maximum and minimum possible scores were 200 and 40 respectively. Whereas the maximum and minimum scores obtained were 160 and 97 respectively. The total score of all respondents was arrived by multiplying the frequency of responses under each of the sub item of practice with corresponding weightage. The mean score of each sub item of practice was arrived from dividing total score with number of respondents and sub items were ranked based on mean scores.

\section{Categorization}

The respondents were grouped into following three categories i.e. low, medium and high based on inclusive class interval technique.

Utilisation of DAATTC services was arrived by summing up of extent of utilisation and extent of adoption of respondents. Maximum and minimum scores obtained were 334 and 247 respectively.

\section{Categorization}

The respondents were grouped into following three categories i.e. low, medium and high utilisation of DAATTC services based on inclusive class interval technique. 
Table.1 Selection of aspects to measure extent of utilisation of services

\begin{tabular}{|c|c|c|c|c|c|c|c|}
\hline S No & Services & HR & $\mathbf{R}$ & NR & TS & MS & MS \\
\hline I & \multicolumn{6}{|c|}{ Services through assessment and refinement of technology } & \\
\hline 1 & Coverage of complete information & 12 & 6 & 2 & 50 & 2.50 & 3 \\
\hline 2 & Timeliness of service & 4 & 12 & 4 & 40 & 2.00 & 2 \\
\hline 3 & Opportunity for feed back & 14 & 3 & 3 & 51 & 2.55 & 3 \\
\hline 4 & $\begin{array}{l}\text { Consideration of suggestions for refinement of } \\
\text { technology }\end{array}$ & 13 & 5 & 2 & 51 & 2.55 & 3 \\
\hline 5 & Imparted farming situation based technologies & 17 & 3 & 0 & 57 & 2.85 & 3 \\
\hline 6 & Suitability of service to the respondent & 11 & 5 & 4 & 47 & 2.35 & 2 \\
\hline 7 & Satisfaction of past performance of service & 10 & 7 & 3 & 47 & 2.35 & 2 \\
\hline II & \multicolumn{6}{|l|}{ Diagnostic services } & \\
\hline 1 & Coverage of complete information & 17 & 2 & 1 & 56 & 2.80 & 3 \\
\hline 2 & Timeliness of service & 16 & 3 & 1 & 55 & 2.75 & 3 \\
\hline 3 & Need based services & 16 & 2 & 2 & 54 & 2.70 & 3 \\
\hline 4 & Services solves problem & 13 & 6 & 1 & 52 & 2.60 & 3 \\
\hline 5 & Satisfaction of past performance of service & 15 & 1 & 4 & 51 & 2.55 & 3 \\
\hline III & \multicolumn{6}{|c|}{ Services through information centre and supply of information material } & \\
\hline 1 & Provision of holistic information & 13 & 2 & 5 & 48 & 2.40 & 2 \\
\hline 2 & Provision of information material & 5 & 11 & 4 & 41 & 2.05 & 2 \\
\hline 3 & Timeliness of service & 8 & 10 & 2 & 46 & 2.30 & 2 \\
\hline 4 & Services solves problem & 5 & 13 & 2 & 43 & 2.15 & 2 \\
\hline 5 & Access to concerned officials & 8 & 8 & 4 & 44 & 2.20 & 2 \\
\hline 6 & Suitability of service to the respondent & 6 & 9 & 5 & 41 & 2.05 & 2 \\
\hline 7 & Trustworthy of Service & 12 & 6 & 2 & 50 & 2.50 & 3 \\
\hline 8 & Satisfaction of past performance of service & 2 & 8 & 10 & 32 & 1.60 & 2 \\
\hline IV & \multicolumn{6}{|l|}{ Services through training programmes } & \\
\hline 1 & Provision of complete information & 7 & 3 & 10 & 37 & 1.85 & 2 \\
\hline 2 & Timeliness of service & 8 & 2 & 10 & 38 & 1.90 & 2 \\
\hline 3 & Need based services & 10 & 7 & 3 & 47 & 2.35 & 2 \\
\hline 4 & Suitability of service to the respondent & 11 & 4 & 5 & 46 & 2.30 & 2 \\
\hline 5 & Satisfaction of past performance of service & 13 & 3 & 4 & 49 & 2.45 & 2 \\
\hline V & \multicolumn{6}{|l|}{ Services through RAWEP students } & \\
\hline 1 & Provision of complete information & 12 & 3 & 5 & 47 & 2.35 & 2 \\
\hline 2 & Timeliness of service & 9 & 4 & 7 & 42 & 2.10 & 2 \\
\hline 3 & Suitability of service to the respondent & 5 & 6 & 9 & 36 & 1.80 & 2 \\
\hline 4 & Satisfaction of past performance of service & 11 & 3 & 6 & 45 & 2.25 & 2 \\
\hline VI & \multicolumn{6}{|l|}{ Technology transfer } & \\
\hline A & \multicolumn{6}{|l|}{ Technology aspects } & \\
\hline 1 & Imparted simple technology & 15 & 4 & 1 & 54 & 2.70 & 3 \\
\hline 2 & Disseminated affordable technology & 13 & 7 & 0 & 53 & 2.65 & 3 \\
\hline 3 & Trialability of technology & 9 & 7 & 4 & 45 & 2.25 & 2 \\
\hline
\end{tabular}




\begin{tabular}{|c|c|c|c|c|c|c|c|}
\hline 4 & Technology observability & 12 & 2 & 6 & 46 & 2.30 & 2 \\
\hline 5 & Technology replicability & 14 & 2 & 4 & 50 & 2.50 & 3 \\
\hline B & Ways and means of technology transfer & & & & & & \\
\hline 1 & Utilisation of group meetings & 7 & 12 & 1 & 46 & 2.30 & 2 \\
\hline 2 & Utilisation of kisan meals & 9 & 9 & 2 & 46 & 2.30 & 2 \\
\hline 3 & Utilisation of study tours & 8 & 10 & 2 & 45 & 2.25 & 2 \\
\hline 4 & Utilisation of field days & 14 & 3 & 3 & 49 & 2.45 & 2 \\
\hline 5 & Utilisation of minikit trials & 11 & 7 & 4 & 48 & 2.40 & 2 \\
\hline 6 & Utilisation of demonstrations & 12 & 6 & 2 & 49 & 2.45 & 2 \\
\hline 7 & Utilisation of exhibitions & 11 & 4 & 5 & 42 & 2.10 & 2 \\
\hline VII & Other services & & & & & & \\
\hline 1 & Provision of market intelligence & 11 & 4 & 5 & 46 & 2.30 & 2 \\
\hline 2 & Mechanization aspects covered & 4 & 14 & 2 & 42 & 2.10 & 2 \\
\hline 3 & Details of input source availability & 5 & 13 & 2 & 43 & 2.15 & 2 \\
\hline 4 & Orientation to own input production & 6 & 10 & 4 & 42 & 2.10 & 2 \\
\hline 5 & Relevance of services to climatic change & 4 & 10 & 6 & 38 & 1.90 & 2 \\
\hline 6 & Information on natural resources management & 9 & 12 & 1 & 52 & 2.60 & 3 \\
\hline
\end{tabular}

Table.2 Distribution of respondents based on extent of utilisation of services

\begin{tabular}{|c|c|c|c|}
\multirow{2}{*}{ S. No. } & \multicolumn{2}{|c|}{$\mathrm{n}=120$} \\
& Category & Frequency & Percentage (\%) \\
\hline $\mathbf{1}$ & & 15 & 12.50 \\
\hline $\mathbf{2}$ & Low & 72 & 60.00 \\
\hline $\mathbf{3}$ & Medium & 33 & 27.50 \\
\hline
\end{tabular}

Table.3 Distribution of respondents based on extent of adoption in cotton $\mathrm{n}=120$

\begin{tabular}{|c|c|c|c|}
\hline S. No. & Category & \multicolumn{2}{|c|}{ Respondents } \\
\hline & & Frequency & Percentage (\%) \\
\hline $\mathbf{1}$ & Low & 19 & 15.83 \\
\hline $\mathbf{2}$ & Medium & 86 & 71.67 \\
\hline $\mathbf{3}$ & High & 15 & 12.50 \\
\hline
\end{tabular}

Table.4 Distribution of respondents based on their utilisation of DAATTC services

\begin{tabular}{|c|c|c|c|}
\hline \multirow{2}{*}{ S. No. } & \multirow{2}{*}{ Category } & \multicolumn{2}{|c|}{ Respondents } \\
\hline & & Frequency & Percentage (\%) \\
\hline $\mathbf{1}$ & Low & 21 & 17.50 \\
\hline $\mathbf{2}$ & Medium & 75 & 62.50 \\
\hline $\mathbf{3}$ & High & 24 & 20.00 \\
\hline
\end{tabular}




\section{Category of utilization}

\begin{tabular}{|l|c|}
\hline Category of utilization & Range \\
\hline Low & $120-146$ \\
\hline Medium & $146-172$ \\
\hline High & $172-198$ \\
\hline
\end{tabular}

\section{Category of adoption}

\begin{tabular}{|l|c|}
\hline Category of adoption & Range \\
\hline Low & $97-118$ \\
\hline Medium & $118-139$ \\
\hline High & $139-160$ \\
\hline
\end{tabular}

Category of utilisation

\section{Category of utilisation}

\begin{tabular}{|l|}
\hline Low \\
\hline Medium \\
\hline High
\end{tabular}

\section{Range}

$247-276$

276-305

305-334
Total obtained scores on all items on extent of utilisation and adoption Utilisation index $=$ $\times 100$

Maximum possible scores on all items on extent

\section{Results and Discussion}

Utilisation of services of district agricultural advisory and transfer of technology centre by farmers

\section{Extent of utilisation}

It could be indicated from the Table. 2 that majority $(60.00 \%)$ of the respondents had medium extent of utilisation of services followed by high (27.50\%) and low (12.50\%) utilisation of services.

It could be inferred that majority of the respondents had medium extent of utilisation of services due to illiteracy, small farm size, medium annual income, medium innovativeness, medium information seeking behaviour, medium social participation and medium participation in DAATTC activities.

Extent of adoption of recommended practices in cotton

It could be indicated from the Table. 3 that majority $(71.67 \%)$ of the respondents had medium adoption in cotton followed by low $(15.83 \%)$ and high $(12.50 \%)$. The medium extent of adoption of recommended practices was observed because of less opportunity for feedback and consideration of farmers' suggestions for refinement of technologies.

\section{Utilisation of DAATTC services}

It could be indicated from the Table. 4 that majority $(62.50 \%)$ of the respondents had medium utilisation of DAATTC services followed by high $(20.00 \%)$ and low $(17.50 \%)$ utilisation of DAATTC services.

The above finding can be attributed to medium extent of utilisation (Table 1) and medium extent of adoption (Table 2). Utilisation index is 
calculated as per formula given in methodology and given under.

Utilisation index $=\frac{334}{435} \times 100=76.78 \%$

Thus, it can be noted that DAATTC has provided indefatigable services for the respondents.

As majority of farmers felt that as observability of slow moving i.e., maintenance of refugee crop, seed treatment, bio fertilizer applications, biological control measures usage in cotton crop was less, so was their adoption.

Hence, DAATTC scientists and other stakeholders have to concentrate on these aspects by creating awareness among the farmers, finally convince them through media mix of demonstrations, field days, minikit trials, video presentations and conducting group meetings regularly in model farm of innovative farmers fields. For innovative farmers honorarium should be paid as they in turn train 20 master trainers in mandal to train farmer friends of ATMA who in turn trains farmer interest groups of ATMA at village level. Hence, DAATTC has to link up with the ATMA network in transfer of technology. Moreover, exposure visits to successful fields was suggested by farmers in the study. This method may be considered and innovative farmers may be utilised for this purpose.

Timely follow up of each and every technology transferred was most important to be attended by DAATTC scientists to facilitate technology assessment and refinement which helps in effective utilisation.

\section{References}

Chinchamalapure, U.R., Rajput, H.D and Girase, C.P. 2009. Utilisation, credibility and effectiveness of communication media among Bt cotton growers. Journal of Agricultural Extension Management. 10(2): 99-104.

Desai, G.R and Manohari, P.L. 2009. Utilisation of animal husbandry extension services by rainfed farmers. Journal of Agricultural Extension Management. 10 (1): 37-45.

Desai, G.R., Manohari, P.L and Kumar, T.D.S., 2009. Utilisation of agricultural research and extension services by rainfed farmers. Journal of Agricultural Extension Management. 10 (1): 1-11.

Kotele, R, T., Suradkar, D.D and Bhople. 2009. Determinations of utility perception of telecast agricultural technologies. Journal of Agricultural Extension Management. 10 (2): 71-76.

Kumar, B. Asokhan, M., Palaniswamy, S and Ravichandran, V. 2012. Utilization behaviour of potato growers between cooperative and private cold storage unit. Journal of Extension Education. 24 (1): 4755-4760.

Manohari, P.L. 2002. Utilisation of information sources by the tribal farmers in Rampachodavaram agency area - A micro study. Manage Extension Research Review. 3(2): 132-136.

Rao, I.S. 1995. Perception of mango growers about utility of fruit research station Sangareddy. Journal of Research. 23(3):3133.

Sendilkumar, R., Fernandaz, C.C., Karpagam, C and Asokhan, M. 2010. Farm front extension services at the Uzhavar Udhaviyagam- A formative evaluation. Journal of Extension Education. 22 (1): 4357- 4365 .

\section{How to cite this article:}

Neethi, B. and Sailaja, A. 2018. Development of Extension Service Utilisation Index. Int.J.Curr.Microbiol.App.Sci. 7(05): 2685-2691. doi: https://doi.org/10.20546/ijcmas.2018.705.311 